\title{
The Impact of RMB Exchange Rate Fluctuation on Enterprises' Export Decisions-From the Perspective of Heterogeneity
}

\author{
Wenhua Liu \\ Jinan University, Guangzhou, China \\ Email: 15667097015@163.com
}

How to cite this paper: Liu, W. H. (2020). The Impact of RMB Exchange Rate Fluctuation on Enterprises' Export Decisions-From the Perspective of Heterogeneity. Modern Economy, 11, 920-937. https://doi.org/10.4236/me.2020.114069

Received: February 27, 2020

Accepted: April 19, 2020

Published: April 22, 2020

Copyright $\odot 2020$ by author(s) and Scientific Research Publishing Inc. This work is licensed under the Creative Commons Attribution International License (CC BY 4.0).

http://creativecommons.org/licenses/by/4.0/

\begin{abstract}
This paper empirically discusses the impact of exchange rate fluctuations on enterprises' export decisions by using the annual data of the database of China's industrial enterprises and the database of China's customs merged according to the hs6-digit code from 2000 to 2007. The study found that: 1) the appreciation of RMB real effective exchange rate will significantly increase the probability of enterprises exiting export markets and reduce the probability of enterprises entering export markets; 2) compared with state-owned enterprises and private enterprises, foreign-owned enterprises have stronger ability to fight against exchange rate risks, and enterprises in eastern China are more sensitive to exchange rate fluctuation; 3 ) based on the analysis of heterogeneity of enterprise characteristics, it is found that such factors as enterprise productivity, enterprise profit margin, enterprise size and enterprise export experience can reduce the positive impact of RMB real effective exchange rate appreciation on enterprises exiting from export markets. This paper provides some useful advice for enterprises to avoid exchange rate risks and make better export decisions.
\end{abstract}

\section{Keywords}

RMB Real Effective Exchange Rate, Enterprise Export Decision, Heterogeneity

\section{Introduction}

Since China joined the WTO, China's export trade has shown an "extraordinary" prosperity. China's total exports grew nearly tenfold from \$249 billion in 2000 to $\$ 2487$ billion in 2018 , with an average annual growth rate of about 50 
percent. During this period, net exports, one of the "troikas" driving China's economic development, gave a big boost to China's economic growth. However, at the same time, the rapid growth of trade also aggravates China's external dependence, and the frequent fluctuation of the international situation greatly affects the growth margin of China's trade export. Since the 2008 financial crisis, the global economic slowdown and anti-globalization leads to the deterioration of the external macro fundamentals which bring a lot of obstacles and uncertainty to China's export. China's exports value and export growth slowed sharply, in 2009 China's total exports value was only $\$ 120.2$ billion and the export growth started a sharp decline into $16.01 \%$. Subsequently, the international community gradually recovered from the shadow of the financial crisis. From 2009 to 2014, China's export value had been in a slow growth stage, but the export growth rate gradually declined. China's trade growth rate in 2015 and 2016 was $-2.94 \%$ and $-7.73 \%$ respectively. Global trade has entered a period of profound adjustment, which has inhibited China's export growth. At present, scholars at home and abroad have investigated the impact of these factors on enterprises' export decisions from the perspectives of export country characteristics (Osnago et al., 2015), export product types (Hess \& Persson, 2011), enterprise characteristics (Gorg et al., 2012), and trade policy uncertainty (Handley, 2014). In contrast, few scholars have studied the export decisions of enterprises from the perspective of exchange rate fluctuations.

In fact, in the international trading system, apart from routine trade risks such as trade disputes and trade barriers, exchange rate fluctuations are also an external uncertainty factor that is difficult to avoid. The uncertainty of exchange rate fluctuations directly affects the international price of export products, affects the balance of international payments of exporting countries, and further affects the export expectation and export quantity of enterprises. In terms of the reality of China's economic development, after three exchange rate reforms, the RMB has entered the era of "two-way floating", the RMB value is becoming more market-oriented, and the internationalization degree of the RMB exchange rate is also continuously improving, which will undoubtedly lead to more frequent fluctuations of the RMB real effective exchange rate.

Moreover, from the perspective of China's export structure, China is an export power rather than an export power, which is mainly reflected in the fact that China's export products tend to have low added value, are in a lower position in the global value chain, and their export quality is not high. Enterprises are the carrier of trade and the direct subject. In the context of China's economic transformation, it is of far-reaching significance to deeply study the export decisions of enterprises in the transformation from "unconventional" development mode to "new normal" development mode. The uncertainty of exchange rate fluctuations will cause export enterprises to choose to suspend or delay export, because under the exogenous impact of high uncertainty, enterprises are in the consideration of risk avoidance, and their export decisions will be more cautious 
(Bloom et al., 2007), which brings great challenges to the business strategy deployment of enterprises. The increase of uncertainty of exchange rate fluctuations will significantly increase the uncertainty of future profitability of export enterprises (Bonaime et al., 2018). Moreover, exchange rate fluctuations are a frequent and long-term factor, which will further lead to the difficulty for enterprises to make the best business decisions.

In this context, what impact will exchange rate fluctuations have on the export decisions of China's enterprises, especially the export decisions of low-value-added products? This is undoubtedly a problem worthy of attention in current research. The purpose of this paper is to make empirical research on this issue. Specifically, based on annual data of 2000-2007 China's industrial enterprise database and China's customs database according to the HS6 digit code and construct a three-dimensional data of "enterprise-product-destination" detailed to the product level, this paper build the measure of exchange rate fluctuations and export enterprises decision-making, and empirically study the impact of exchange rate fluctuations on enterprises' export decisions, and expand further based on the perspective of heterogeneity.

\section{Literature Review}

The exchange rate as a relatively exogenous uncertainty factor is closely related to the export behavior of enterprises (Frankle \& Wei, 2007). From the majority of research results, the impact of exchange rate fluctuation on the export decisions of micro-enterprises is mainly reflected in two aspects: The first is the price transfer effect of exchange rates. That is, fluctuation in the exchange rate will change the export prices of exporters and also affect the balance of payments of the exporting countries, which will further affect the expectations of enterprises and the choice of export strategies. This reflects the transfer effect of exchange rates (Dornbusch, 1987; Dixit, 1989). The second is the impact of exchange rate fluctuations on the margins of corporate exports. The export margin of an enterprise is mainly divided into two aspects: intensive margin and extensive margin. In the long run, the impact of exchange rate fluctuations on corporate exports is mainly the expansion margin, while in the short term it is the intensive margin. This article will mainly summarize the related research results on the extent to which exchange rate fluctuation affect enterprises' export decisions.

Melitz (2003) first introduced the concept of corporate heterogeneity. The micro-enterprise heterogeneity model he built explored the relationship between corporate heterogeneity and export decisions from the perspective of the enterprise. Melitz (2003) believes that the export decisions of enterprises are mainly determined by productivity. Generally, the enterprises with higher productivity can enter the export markets, while the enterprises with lower productivity can only operate locally or even exit the export markets. Exchange rate fluctuation is an important factor affecting productivity (Feenstra, 1989). Tomlin and Fung (2010) analogized exchange rate fluctuation to tariff barriers. The increase in the 
price of domestically priced export goods due to the appreciation of the exchange rate is similar to the increase in import tariffs, and vice versa. Therefore, from this perspective, exporters with higher productivity are more likely to achieve economies of scale and slow down the negative effects of sharp exchange rate fluctuations (Fung, 2008). Through research and analysis of Taiwanese enterprise productivity, Fung (2008) believes that the appreciation of the real effective exchange rate will "crowd out" the export markets from the lower productivity enterprises, while leaving the higher productivity enterprises to more easily obtain economies of scale. Baggs et al. (2009)'s investigation of Canadian export enterprises has similar results. Berman et al. (2012) found that when the exchange rate depreciates, more enterprises will choose to enter the export markets. But the enterprises with different productivity have different performance. High-productivity enterprises will choose to increase export prices, while low-productivity enterprises will choose to increase export volume. This difference is also reflected in the export products of enterprises. Chattrejee et al. (2013) examined Brazil's customs data from 1997 to 2006, and found that when the exchange rate depreciated, enterprises would choose to export more core products rather than marginal products; Manova and Zhang (2012) studied China's data also reached the same conclusion. At the same time, enterprises will further increase the number of types of exports (Berthou \& Fontagné, 2013). Generally speaking, exporters are mostly multi-product exporters (Melitz \& Ottaviano, 2008). Because the exogenous shock of exchange rate fluctuation is often uncertain, and the export competitiveness of multi-product export enterprises is relatively strong, has comparative advantages, and has more choices in export decisions (Eckel \& Neary, 2010). Enterprises entering and exiting export markets are the main export decision mechanisms of enterprises, and this behavior will be accelerated when the degree of exchange rate fluctuation increases. Foster et al. (2001) examined the US apparel export data and found that frequent fluctuations in the US dollar from 1977 to 1987 caused 40\% of apparel enterprises to withdraw from the export markets. The direct explanation of this result is that frequent fluctuation in exchange rates directly affects the profit margins of enterprises, and ultimately affects the export decisions of enterprises. Considering the acceleration of the internationalization process of the RMB exchange rate, more and more research focuses on the export behavior of China's enterprises. Tang and Zhang (2012) used China's micro-enterprise database analysis to find that fluctuation in the RMB exchange rate have a significant impact on China's enterprises to entering or exiting the export markets. Specifically, appreciation of the RMB exchange rate will reduce the probability of enterprises entering new export market and increase the probability of enterprises exiting the export markets. Freund et al. (2011) used the customs database of 1997-2005 to measure the import and export elasticity of enterprises with different trading methods to the RMB exchange rate. The study found that export enterprises in processing trade are not sensitive to exchange rate fluctuation, and the export enterprises that need more inputs of production factors are more sensitive to 
exchange rate fluctuation. At the same time, research by Obstfeld and Rogoff (2000) also pointed out that the impact of exchange rate fluctuation on exports was little, and for the first time put forward the argument of "the mystery of invalid exchange rates".

Due to the existence of China's export expansion margin, the large number of foreign-owned enterprises, and the backwardness of China's external financial market, the impact of exchange rate fluctuation on China's export decision-making is still worth exploring. And from the research results of scholars, there are still some deficiencies. On this basis, this article has made some new extensions. First, this paper uses 2000-2007 China's industrial enterprise database and China's customs database to merge annual data according to the HS6 digit code and construct a three-dimensional data of "enterprise-product-destination" detailed to the product level, avoiding the endogenous bias caused by macro data in previous research The. Second, consider the export decision of the enterprises. This article firstly defines the decision model for enterprises entering or exiting export markets, empirically tests the probability of the impact of exchange rate fluctuation on enterprises entering or exiting export markets, and further examines the impact of enterprise heterogeneity at different levels. This is beneficial to further characterize the dynamic behavior of enterprises exports.

\section{Data and Methodological Framework}

\subsection{Empirical Models}

At this point, the export decision behavior of the enterprise is a binary dummy variable. This includes whether the enterprise exits export markets or enters export markets. Therefore, this paper selects probit model to test the impact of exchange rate fluctuations on enterprises' export decision behavior. The model of this paper is set as:

$$
\begin{aligned}
& \operatorname{probit}_{\left(\text {exit }_{i j k t}=1\right)}=\Phi\left(\alpha_{0}+\alpha_{1} \ln \text { reer }_{i j k t}+\eta X_{i j k t}+\mu\right) \\
& \operatorname{probit}_{\left(\text {enter }_{i j k t}=1\right)}=\Phi\left(\alpha_{0}+\alpha_{1} \ln \text { reer }_{i j k t}+\eta X_{i j k t}+\mu\right)
\end{aligned}
$$

where, subscripts $i, j, k$ and $t$ represent the enterprise, country of destination, product and year respectively. exit $t_{i k t}$ indicates whether the enterprise chooses to exit from export markets; enter $r_{i j k}$ indicates whether the enterprise chooses to enter export markets. The function $\Phi(\cdot)$ is a normal cumulative distribution function, which is used to estimate the probability of enterprises exiting or entering export markets. $\ln$ reer $_{i j k t}$ is the real effective exchange rate at the enterprise level; $X_{i j k t}$ is a series of control variables; $\mu$ represents the random disturbance term. The probit model measures the probability of an enterprise exiting or entering export markets.

\subsection{Measurement of Major Variables}

1) Exchange rate fluctuation. Referring to the measurement method of $\mathrm{Bi}$ ni-Smaghi (1991), this paper uses the real effective exchange rate faced by enter- 
prises to measure the exchange rate fluctuation in the benchmark regression. The specific calculation formula is as follows:

$$
\begin{aligned}
\text { reer }_{t}= & \prod_{j=1}^{n}\left(E_{j t} * \frac{c p i_{t}}{c p i_{j t}}\right)^{w_{j, t}} \\
& \sum_{j=1}^{n} w_{j}=1 \text { for each } t
\end{aligned}
$$

where, $j$ stands for different countries; $t$ is for time, and here is year; reer represents the real effective exchange rate faced by enterprises after removing the price level; $c p i_{t}$ is the consumer price index of China in period $t, c p i_{j t}$ represents the consumer price index of country $j$ in period $t, E_{j t}$ represents the price of foreign currency against RMB in period $t$, which is measured by the indirect quotation method; $w_{j t}$ is the trade weight. Therefore, the rise of reer $t_{t}$ represents the appreciation of the RMB exchange rate faced by enterprises, while the decline represents the depreciation of the RMB exchange rate faced by the enterprise.

2) Enterprise export decisions. As for the definition of enterprise exiting or entering export markets, this paper defines the export dynamics of enterprises in period $t-1$ and period $t$. Since the data structure of this paper is to construct the export fragment of enterprise, product and export destination country into a three-dimensional structure of "enterprise-product-destination" in the form of one-to-one correspondence, in the sample period, only the fragments with export behavior are retained in this paper. Therefore, this paper defines: if the same export fragment does not exist in period $t-1$, and the export fragment exists in period $t(t \geq 1)$, it means that the enterprise enters export market (enter), and the value is " 1 "; otherwise, it is " 0 ". If there is an export segment in period $t$ -1 of the enterprise, and the same export segment in period $t$ does not exist $(t \geq$ 1 ), then the enterprise exits export markets (exit), and the value is " 1 "; otherwise, it is " 0 ". At this point, enterprise enter and exit from export market are binary dummy variables. It is worth explaining that, due to the lack of left and right issues, the last period is not out of export market, the first period is not into export markets. Since the sample period selected in this paper is from 2000 to 2007, the data will be deleted on the year in the actual regression.

3) Other control variables. In order to control more heterogeneous characteristics as much as possible, this paper classifies the control variables according to national characteristics, enterprise characteristics and product characteristics in a multi-level way by referring to Gorg et al. (2012). The variables of national characteristics are similar to those of the traditional trade gravity model, including the national size and the level of economic development of the exporting destination nation, which are mainly measured by the GDP of the destination nation (Ingdp) and the per capita GDP of the destination nation (Ingdppc), and bilateral trade distance (Indistance). The variables of enterprise characteristics mainly cover the operating state and productivity level of enterprises, including 
total factor productivity (tfp), enterprise profit margin (profit), enterprise size (Insize), enterprise age (Inage) and enterprise export experience (exp) and so on. Total factor productivity ( $t f p$ ) is estimated by using the semi-parameter estimation method proposed by Levinsohn and Petrin (2003). The profit margin of enterprise (profit) is the ratio of its operating profit to its income. Enterprise size (Insize) is measured by the stock of fixed assets. Enterprise age (Inage) is measured by the duration of the enterprise since its establishment. Enterprise's export experience (exp) is a binary dummy variable, depending on whether the enterprise has exported the same product before, the value is "1" if it has, otherwise, it is " 0 ". Finally, the product characteristic variables mainly include the product export value (Invalue), the product export share (share) and the product export variety (Invariety).

\subsection{Data}

The data in this paper are based on the annual data matching according to the hs6-digit code of China's industrial enterprise database and customs database from 2000 to 2007. Among them, the China's customs database contains all the import and export enterprises in China, including the import and export types, types and amounts of import and export commodities, types of enterprise ownership, and destinations of export commodities. China's industrial enterprise database is based on the national bureau of statistics which includes industrial enterprises above the scale of industrial legal person, all state-owned and non-state-owned enterprises with annual main business income of more than 5 million yuan, covering about $95 \%$ of China's industrial output. Due to the encoding difference between the two sets of databases, it is necessary to process and match the two sets of databases. Generally, this paper followed the match method of Upward et al. (2013).

To be specific, firstly, some missing values and error values were deleted from two sets of databases, and the two databases were directly matched according to the enterprise name, and some missing variables were deleted. Secondly, the export fragments of the merged China's enterprises are constructed according to the three-dimensional structure of "enterprise-product-destination" after the missing value is deleted. In the end, a combined total of 4,447,082 export fragments were retained. Data on exchange rates come from the international monetary fund's database of international financial statistics. The data of national characteristic variables and product characteristic variables are from China's customs database. The data of enterprise characteristic variables are all from the database of China's industrial enterprises. Descriptive statistics for main variables are shown in Table 1.

The descriptive statistical table measures the observed value (Obs), Mean value (Mean), standard deviation (Std. Dev.), minimum value (Min) and maximum value (Max) of main variables.

Table 2 measures the correlation analysis between two variables. The correla- 
tion coefficient shows that there is no serious correlation between variables, which avoids the multi-collinearity that may occur in regression.

Table 1. Descriptive statistics of main variables.

\begin{tabular}{|c|c|c|c|c|c|}
\hline Variables & Obs & Mean & Std. Dev. & Min & Max \\
\hline exit & $4,447,082$ & 0.3849 & 0.4865 & 0 & 1 \\
\hline enter & $4,447,082$ & 0.6426 & 0.4792 & 0 & 1 \\
\hline lnreer & $4,447,082$ & 1.2963 & 1.81175 & 0.0352 & 8.0158 \\
\hline $\operatorname{lngdp}$ & $4,447,082$ & 27.2492 & 1.8273 & 18.6212 & 30.3427 \\
\hline $\operatorname{lngdppc}$ & $4,447,082$ & 9.8391 & 1.1804 & 5.2723 & 11.6259 \\
\hline Indistance & $4,447,082$ & 8.5647 & 0.7512 & 6.8634 & 9.8614 \\
\hline $\mathrm{tfp}$ & $4,447,082$ & 6.4354 & 0.9776 & 2.1702 & 8.5609 \\
\hline profit & $4,447,082$ & 0.0328 & 0.0717 & -0.5446 & 0.3145 \\
\hline lnsize & $4,447,082$ & 9.0782 & 1.6046 & 4.3174 & 12.7278 \\
\hline lnage & $4,447,082$ & 2.0487 & 0.7124 & 0 & 5.6058 \\
\hline $\exp$ & $4,447,082$ & 0.5299 & 0.4991 & 0 & 1 \\
\hline lnvalue & $4,447,082$ & 9.4428 & 2.5109 & 0 & 20.7225 \\
\hline share & $4,447,082$ & 0.2968 & 0.3687 & $8.63 \mathrm{E}-10$ & 1 \\
\hline lnvariety & $4,447,082$ & 2.5335 & 1.4235 & 0 & 6.9488 \\
\hline
\end{tabular}

Data sources: China's industrial enterprise database and customs database from 2000 to 2007.

Table 2. Correlation analysis of main variables.

\begin{tabular}{|c|c|c|c|c|c|c|c|c|c|c|c|c|c|c|}
\hline & exit & enter & lnreer & $\operatorname{lngdp}$ & lngdppc & Indistance & tfp & profit & lnsize & lnage & $\exp$ & lnvalue & share & lnvariety \\
\hline exit & 1.000 & & & & & & & & & & & & & \\
\hline enter & 0.031 & 1.000 & & & & & & & & & & & & \\
\hline lnreer & 0.018 & 0.010 & 1.000 & & & & & & & & & & & \\
\hline $\operatorname{lngdp}$ & $(0.039)$ & $(0.090)$ & $(0.129)$ & 1.000 & & & & & & & & & & \\
\hline $\operatorname{lngdppc}$ & $(0.036)$ & $(0.076)$ & $(0.468)$ & 0.568 & 1.000 & & & & & & & & & \\
\hline Indistance & 0.018 & 0.034 & $(0.429)$ & 0.066 & $(0.015)$ & 1.000 & & & & & & & & \\
\hline $\mathrm{tfp}$ & 0.014 & $(0.076)$ & $(0.010)$ & $(0.012)$ & $(0.027)$ & 0.078 & 1.000 & & & & & & & \\
\hline profit & $(0.049)$ & 0.031 & 0.010 & $(0.007)$ & $(0.027)$ & 0.013 & 0.270 & 1.000 & & & & & & \\
\hline lnsize & 0.061 & $(0.118)$ & 0.035 & $(0.035)$ & $(0.077)$ & 0.039 & 0.403 & 0.047 & 1.000 & & & & & \\
\hline lnage & 0.069 & $(0.163)$ & 0.020 & $(0.010)$ & $(0.031)$ & 0.010 & 0.144 & $(0.027)$ & 0.300 & 1.000 & & & & \\
\hline $\exp$ & 0.036 & $(0.478)$ & $(0.014)$ & 0.003 & $(0.002)$ & 0.079 & 0.170 & $(0.014)$ & 0.177 & 0.257 & 1.000 & & & \\
\hline lnvalue & $(0.121)$ & $(0.308)$ & 0.013 & 0.116 & 0.035 & 0.007 & 0.085 & $(0.009)$ & 0.119 & 0.062 & 0.213 & 1.000 & & \\
\hline share & $(0.041)$ & $(0.185)$ & $(0.000)$ & $(0.084)$ & $(0.098)$ & 0.117 & $(0.014)$ & $(0.001)$ & 0.041 & 0.037 & 0.232 & 0.403 & 1.000 & \\
\hline lnvariety & $(0.149)$ & 0.190 & $(0.010)$ & $(0.038)$ & 0.024 & $(0.074)$ & 0.021 & 0.048 & $(0.081)$ & $(0.090)$ & $(0.257)$ & $(0.305)$ & $(0.615)$ & 1.000 \\
\hline
\end{tabular}

Note: The value in parentheses () is negative. 


\section{Regression Results and Analysis}

\subsection{Baseline Estimations}

Table 3 shows the regression results of the impact of RMB real effective exchange rate fluctuations on enterprises exiting from export markets. The estimated results are shown in columns (1) to (7). Column (1) is listed as the direct impact of exchange rate fluctuations on enterprises exiting from export markets, and columns (2), (3) and (4) are the regression results after gradually adding control variables such as national characteristics, enterprise characteristics and product characteristics. The regression results show that the regression coefficient of RMB real effective exchange rate (Inreer) has been significantly positive, which indicates that the appreciation of RMB real effective exchange rate significantly increases the probability of enterprises exiting export markets. This is because when the local currency appreciates, the nominal price of the products exported by the enterprises in the international market will be higher, which will restrain their trade flow. The decrease of export markets demand will affect the change of export behavior of enterprises, so enterprises will choose to temporarily suspend the export or give up the export markets. This is consistent with the research conclusion of Tomlin and Fung (2010). In addition, since the exchange rate measurement process involves the data of many countries, and from the perspective of the index structure, the exchange rate fluctuation will have an impact on the trade weight, so the exchange rate variables may be endogenous. To address the possible endogeneity of the regression results, columns (5) and (6) used the IV instrumental variable method to re-estimate. Therefore, the paper uses the lag period and lag period of the real effective exchange rate as the instrumental variables. The regression results of the instrumental variables are columns (5) and (6). The estimation results based on instrumental variables show that the regression coefficient of RMB real effective exchange rate is still positive and passes the significance test of $1 \%$ level. It shows that the appreciation of RMB real effective exchange rate will indeed increase the possibility of enterprises exiting from export market, which is consistent with the analysis of fundamental regression. Column (7) is listed as the result of logit model regression. Considering the possible defects of the model itself, this paper chooses 10 git model to re-examine the impact of RMB real effective exchange rate on enterprises exiting from export markets, as the robustness test of basic regression. From the regression results in column (7), it can be seen that the regression coefficient of the real effective exchange rate of $\mathrm{RMB}$ is still positive and has passed the significance test at the $1 \%$ level, and the coefficient and sign of other control variables have not changed substantially, which further guarantees the robustness of the conclusion of this paper.

As for other control variables, the influence of characteristic variables on enterprises exiting from export markets can be seen in columns (2), (3) and (4). As shown in column (2) of Table 3 , among the national characteristic variables, the regression coefficients of national size (lngdp) and economic development level 
Table 3. Regression results of exchange rate fluctuations on enterprises exiting from export markets.

\begin{tabular}{|c|c|c|c|c|c|c|c|}
\hline Exit & $\begin{array}{c}(1) \\
\text { probit }\end{array}$ & $\begin{array}{l}(2) \\
\text { probit }\end{array}$ & $\begin{array}{l}\text { (3) } \\
\text { probit }\end{array}$ & $\begin{array}{c}(4) \\
\text { probit }\end{array}$ & $\begin{array}{c}(5) \\
\text { IV-probit }\end{array}$ & $\begin{array}{c}(6) \\
\text { IV-probit }\end{array}$ & $\begin{array}{l}(7) \\
\text { logit }\end{array}$ \\
\hline \multirow[t]{2}{*}{ lnreer } & $0.0169^{* * *}$ & $0.0163^{\star * *}$ & $0.0166^{* * *}$ & $0.0164^{* * *}$ & $0.0123^{\star * *}$ & $0.0080^{* * *}$ & $0.0277^{\star * *}$ \\
\hline & $(0.0006)$ & $(0.0008)$ & $(0.0007)$ & $(0.0007)$ & $(0.0010)$ & $(0.0016)$ & $(0.0012)$ \\
\hline \multirow[t]{2}{*}{$\operatorname{lngdp}$} & & $-0.0640^{* * *}$ & $-0.0658^{\star * *}$ & $-0.0532^{* * *}$ & $-0.0278^{* * *}$ & $-0.0210^{* * *}$ & $-0.0886^{* * *}$ \\
\hline & & $(0.0007)$ & $(0.0007)$ & $(0.0007)$ & $(0.0009)$ & $(0.0014)$ & $(0.0011)$ \\
\hline \multirow[t]{2}{*}{$\operatorname{lngdppc}$} & & $-0.0044^{\star * *}$ & $-0.0053^{* * *}$ & $-0.0223^{\star * *}$ & $-0.0184^{\star * *}$ & $-0.0197^{\star * *}$ & $-0.0373^{* * *}$ \\
\hline & & $(0.0013)$ & $(0.0012)$ & $(0.0012)$ & $(0.0017)$ & $(0.0027)$ & $(0.0020)$ \\
\hline \multirow[t]{2}{*}{ Indistance } & & $0.0467^{\star * *}$ & $0.0592^{* * *}$ & $0.0681^{* * *}$ & $0.0458^{\star * *}$ & $0.0285^{\star * *}$ & $0.1137^{\star * *}$ \\
\hline & & $(0.0016)$ & $(0.0015)$ & $(0.0015)$ & $(0.0020)$ & $(0.0031)$ & $(0.0025)$ \\
\hline \multirow[t]{2}{*}{$\mathrm{tfp}$} & & & $-0.0039^{* * *}$ & $-0.0052^{* * *}$ & 0.0014 & $0.0139^{* * *}$ & $-0.0084^{* * *}$ \\
\hline & & & $(0.0011)$ & $(0.0010)$ & $(0.0015)$ & $(0.0024)$ & $(0.0018)$ \\
\hline \multirow[t]{2}{*}{ profit } & & & $-0.4953^{* * *}$ & $-0.4371^{\star * *}$ & $-0.5816^{* * *}$ & $-0.7407^{\star * *}$ & $-0.7345^{\star * *}$ \\
\hline & & & $(0.0128)$ & $(0.0124)$ & $(0.0183)$ & $(0.0281)$ & $(0.0208)$ \\
\hline \multirow[t]{2}{*}{ lnsize } & & & $-0.0296^{* * *}$ & $-0.0166^{* * *}$ & $-0.0082^{* * *}$ & $-0.0125^{\star * *}$ & $-0.0274^{* * *}$ \\
\hline & & & $(0.0007)$ & $(0.0006)$ & $(0.0009)$ & $(0.0015)$ & $(0.0011)$ \\
\hline \multirow[t]{2}{*}{ lnage } & & & $0.1369^{* * *}$ & $0.1017^{\star * *}$ & $0.0545^{\star * *}$ & $0.0479^{* * *}$ & $0.1695^{\star * *}$ \\
\hline & & & $(0.0015)$ & $(0.0014)$ & $(0.0021)$ & $(0.0037)$ & $(0.0023)$ \\
\hline \multirow[t]{2}{*}{$\exp$} & & & $-0.2096^{* * *}$ & $-0.1319^{* * *}$ & & & $-0.2202^{* * *}$ \\
\hline & & & $(0.0021)$ & $(0.0021)$ & & & $(0.0036)$ \\
\hline \multirow[t]{2}{*}{ lnvalue } & & & & $-0.1403^{\star * *}$ & $-0.1222^{* * *}$ & $-0.1193^{* * *}$ & $-0.2365^{* * *}$ \\
\hline & & & & $(0.0004)$ & $(0.0006)$ & $(0.0009)$ & $(0.0007)$ \\
\hline \multirow[t]{2}{*}{ share } & & & & $-0.4468^{\star * *}$ & $-0.2659^{* * *}$ & $-0.1980^{* * *}$ & $-0.7429^{* * *}$ \\
\hline & & & & $(0.0033)$ & $(0.0045)$ & $(0.0069)$ & $(0.0056)$ \\
\hline \multirow[t]{2}{*}{ lnvariety } & & & & $-0.0451^{\star \star *}$ & $-0.0682^{\star * *}$ & $-0.0784^{* * *}$ & $-0.0754^{* * *}$ \\
\hline & & & & $(0.0011)$ & $(0.0015)$ & $(0.0023)$ & $(0.0018)$ \\
\hline \multirow[t]{2}{*}{ _cons } & $0.2501^{\star * *}$ & $1.6406^{* * *}$ & $1.5914^{* * *}$ & $2.8872^{* * *}$ & $1.6438^{* * *}$ & $1.3602^{* * *}$ & $4.8313^{\star * *}$ \\
\hline & $(0.0035)$ & $(0.0216)$ & $(0.0221)$ & $(0.0213)$ & $(0.0289)$ & $(0.0446)$ & $(0.0358)$ \\
\hline$N$ & $3,091,342$ & $3,091,342$ & $3,091,342$ & $3,091,342$ & $1,081,054$ & 477,032 & $3,091,342$ \\
\hline Loglikelihood & $-2,045,924.4$ & $-2,038,349.8$ & $-2,029,267.3$ & $-1,929,833.6$ & $1,146,568.6$ & $311,194.52$ & $-1,929,438.5$ \\
\hline Wald chi2 & $36,097.76$ & $49,578.34$ & $69,414.36$ & $242,809.83$ & $85,432.49$ & $37,056.22$ & $225,413.93$ \\
\hline Prob $>$ chi 2 & 0.0000 & 0.0000 & 0.0000 & 0.0000 & 0.0000 & 0.0000 & 0.0000 \\
\hline
\end{tabular}

Note: In brackets is the robust standard error, “***” represents the significance level of $1 \%$, “**” represents the significance level of $5 \%$, and “*” represents the significance level of $10 \%$. The following table is same. 
(Ingdppc) are significantly negative, which indicates that the larger the national size and the higher the economic development level of the destination countries are, the lower the probability of export enterprises exiting export market is. In addition, the coefficient of trade distance (Indistance) is significantly positive, which indicates that the farther the distance is, the higher the probability of enterprises exiting from export markets is. This is consistent with the results of traditional trade gravity models. Column (3) adds regression results for enterprise characteristics variables. Results show that the coefficients of the total factor productivity $(t f p)$, the enterprise profit margin (profit), enterprise size (Ins$i z e)$ and export experience (exp) were significantly negative, this is because the higher productivity, profit margins and enterprise scale are, the better enterprise management status is. The export experience of enterprises indicates that there is a high export stickiness between enterprises and the destination market. These factors all can decrease the probability of enterprises exiting from export markets (Fu \& Wu, 2014). It is worth discussing that the regression coefficient of enterprise age (Inage) is significantly positive, which indicates that the older the enterprise is, the higher the probability that the enterprise will exit from export markets is. This result is consistent with the study on export stability of Spanish export enterprises by Esteve-perez et al. (2013).

Finally, taking into account the product characteristic variables, the regression coefficients of the product's export value (Invalue), export share (share) and export variety (Invariety) are all significantly negative, which indicates that the more the product's export value, export share and export variety are, the lower the probability that the enterprise will exit from export markets is.

Consistent with the model in Table 3, Table 4 estimates the regression results of the impact of RMB real effective exchange rate fluctuations on enterprises to entering export markets. The estimated results are shown in columns (1) to (7). Column (1) is listed as the direct impact of exchange rate fluctuations on enterprises to entering export markets, and columns (2), (3) and (4) as the regression results after gradually adding control variables such as the national characteristics, enterprise characteristics and product characteristics. Columns (5) and (6) are listed as the estimated results of IV instrumental variables, and the decision of instrumental variables is consistent with Table 3. Column (7) is listed as the robustness test result of logit model. From the perspective of regression coefficient, the regression coefficient of RMB real effective exchange rate (Inreer) has been significantly negative, which indicates that the appreciation of RMB real effective exchange rate significantly reduces the probability of enterprises to entering export markets. This is because when the real effective exchange rate of RMB appreciates, the nominal price of export products of enterprises will rise, which inhibits the competitiveness of enterprises in the international market. Enterprises will choose carefully whether to enter export markets or not. The regression coefficients of the other control variables are roughly opposite to those in Table 3. Enterprises exiting from export markets and entering export markets 
are two completely different export decisions, and the same factors have completely opposite influences on enterprises exiting from export markets and entering export markets. Therefore, the following part will mainly investigate the heterogeneity analysis of RMB real effective exchange rate on enterprises exiting from export markets.

Table 4. Regression results of exchange rate fluctuations on enterprises entering export markets.

\begin{tabular}{|c|c|c|c|c|c|c|c|}
\hline Enter & $\begin{array}{l}(1) \\
\text { probit }\end{array}$ & $\begin{array}{l}(2) \\
\text { probit }\end{array}$ & $\begin{array}{l}\text { (3) } \\
\text { probit }\end{array}$ & $\begin{array}{l}(4) \\
\text { probit }\end{array}$ & $\begin{array}{c}(5) \\
\text { IV-probit }\end{array}$ & $\begin{array}{c}(6) \\
\text { IV-probit }\end{array}$ & $\begin{array}{c}(7) \\
\text { logit }\end{array}$ \\
\hline \multirow[t]{2}{*}{ lnreer } & $-0.0077^{\star * *}$ & $-0.0038^{* * *}$ & $-0.0196^{\star * *}$ & $-0.0183^{\star * *}$ & $-0.0053^{* * *}$ & $-0.0103^{* * *}$ & $-0.0295^{\star * *}$ \\
\hline & $(0.0005)$ & $(0.0006)$ & $(0.0008)$ & $(0.0007)$ & $(0.0019)$ & $(0.0030)$ & $(0.0012)$ \\
\hline \multirow[t]{2}{*}{$\operatorname{lngdp}$} & & $0.0630^{* * *}$ & $0.1134^{\star * *}$ & $0.0750^{\star * *}$ & $0.0095^{\star * *}$ & $0.0049^{*}$ & $0.1301^{\star * *}$ \\
\hline & & $(0.0006)$ & $(0.0007)$ & $(0.0007)$ & $(0.0017)$ & $(0.0027)$ & $(0.0012)$ \\
\hline \multirow[t]{2}{*}{ lngdppc } & & $0.0430^{\star \star \star}$ & $0.0433^{\star * *}$ & $0.0563^{* * *}$ & 0.0032 & 0.0066 & $0.0987^{\star \star \star}$ \\
\hline & & $(0.0011)$ & $(0.0013)$ & $(0.0012)$ & $(0.0032)$ & $(0.0050)$ & $(0.0021)$ \\
\hline \multirow[t]{2}{*}{ Indistance } & & $-0.0548^{\star * *}$ & $-0.2593^{\star * *}$ & $-0.2299^{* * *}$ & -0.0009 & -0.0046 & $-0.4010^{\star * *}$ \\
\hline & & $(0.0013)$ & $(0.0017)$ & $(0.0016)$ & $(0.0038)$ & $(0.0060)$ & $(0.0028)$ \\
\hline \multirow[t]{2}{*}{ tfplp } & & & $0.0275^{\star * *}$ & $0.0150^{\star * *}$ & $0.0154^{* * *}$ & $0.0464^{\star * *}$ & $0.0228^{\star * *}$ \\
\hline & & & $(0.0012)$ & $(0.0011)$ & $(0.0028)$ & $(0.0044)$ & $(0.0020)$ \\
\hline \multirow[t]{2}{*}{ profit } & & & $0.3682^{* * *}$ & $0.3386^{* * *}$ & $0.3165^{\star * *}$ & $0.5389^{\star * *}$ & $0.5597^{\star * *}$ \\
\hline & & & $(0.0146)$ & $(0.0140)$ & $(0.0352)$ & $(0.0551)$ & $(0.0246)$ \\
\hline \multirow[t]{2}{*}{ lnsize } & & & $0.0240^{* * *}$ & $0.0047^{\star * *}$ & $0.0394^{* * *}$ & $0.0575^{\star * *}$ & $0.0051^{* * *}$ \\
\hline & & & $(0.0007)$ & $(0.0007)$ & $(0.0018)$ & $(0.0028)$ & $(0.0012)$ \\
\hline \multirow[t]{2}{*}{ lnage } & & & $-0.0306^{\star * *}$ & $-0.0414^{\star * *}$ & $0.0384^{\star \star *}$ & $0.0550^{\star * *}$ & $-0.0699^{* * *}$ \\
\hline & & & $(0.0017)$ & $(0.0016)$ & $(0.0041)$ & $(0.0070)$ & $(0.0028)$ \\
\hline \multirow[t]{2}{*}{$\exp$} & & & $2.7614^{\star * *}$ & $2.5960^{\star * *}$ & & & $4.7773^{\star * *}$ \\
\hline & & & $(0.0039)$ & $(0.0037)$ & & & $(0.0073)$ \\
\hline \multirow[t]{2}{*}{ lnvalue } & & & & $0.1775^{\star \star \star}$ & 0.0002 & 0.0006 & $0.3097^{\star \star *}$ \\
\hline & & & & $(0.0005)$ & $(0.0011)$ & $(0.0018)$ & $(0.0008)$ \\
\hline \multirow[t]{2}{*}{ share } & & & & 0.0040 & $0.0621^{\star * *}$ & $0.0401^{\star * *}$ & 0.0012 \\
\hline & & & & $(0.0035)$ & $(0.0085)$ & $(0.0130)$ & $(0.0060)$ \\
\hline \multirow[t]{2}{*}{ lnvariety } & & & & $0.0039^{\star * *}$ & $-0.0361^{\star * *}$ & $-0.0337^{\star * *}$ & $0.0073^{\star * *}$ \\
\hline & & & & $(0.0011)$ & $(0.0029)$ & $(0.0044)$ & $(0.0019)$ \\
\hline \multirow[t]{2}{*}{ _cons } & $0.9907^{\star * *}$ & $2.6696^{\star * *}$ & $4.4474^{\star * \star}$ & $5.0984^{\star \star \star}$ & $-0.9005^{\star * *}$ & $-1.2778^{* * *}$ & $9.0671^{\star * *}$ \\
\hline & $(0.0017)$ & $(0.0179)$ & $(0.0245)$ & $(0.0235)$ & $(0.0542)$ & $(0.0844)$ & $(0.0410)$ \\
\hline$N$ & $4,238,072$ & $4,238,072$ & $4,238,072$ & $4,238,072$ & $1,359,020$ & 622,509 & $4,238,072$ \\
\hline Loglikelihood & $-2,509,881.5$ & $-2,494,125.7$ & $-1,675,480.7$ & $-1,582,036.3$ & $2,215,164.6$ & $731,122.31$ & $-1,580,739.9$ \\
\hline Wald chi2 & $112,262.19$ & $143,417.59$ & $548,109.44$ & $600,527.62$ & $24,437.18$ & $12,391.18$ & $536,599.99$ \\
\hline Prob $>$ chi2 & 0.0000 & 0.0000 & 0.0000 & 0.0000 & 0.0000 & 0.0000 & 0.0000 \\
\hline
\end{tabular}




\subsection{Regression Results of Different Enterprise Ownership and Enterprise in Different Regions}

Table 5 shows the results of heterogeneous regression after distinguishing the ownership of enterprises and regional differences. Columns (1), (2) and (3) are listed as regression results of different enterprise ownership. Columns (4), (5) and (6) are listed as regression results of enterprises in different regions. In this paper, according to the paid-in capital registered by enterprises, the ownership of enterprises is divided into foreign-owned enterprises (including Hong Kong, Macao and Taiwan), private enterprises and state-owned enterprises, regression results show that when the RMB real effective exchange rate appreciation, the foreign-owned enterprises are less likely to exit than private and state-owned enterprises, while probability of exiting of state-owned enterprises is the highest. This shows that foreign-owned enterprises have more export experience and more technical ability to fight against exchange rate risks (Gorg et al., 2012). In addition, compared with state-owned enterprises and private enterprises, the factor price distortion of foreign-owned enterprises is higher, which is more conducive to the export of enterprises. However, private enterprises tend to be small in scale. From the perspective of enterprise development strategies, what they consider first is not the profit level, but the broader export markets, so they are less likely to exit from export markets. However, the system of state-owned enterprises is often rigid, and they do not take profit as the primary target. They occupy the low financing cost and the monopolized domestic market. State-owned enterprises themselves can obtain excess profits in the domestic market, and they are not keen on export. Therefore, State-owned enterprises are more likely to exit from export market in the face of RMB real effective exchange rate appreciation. From the perspective of regional distribution, enterprises in the eastern region have a high exit probability, while the regression coefficient of enterprises in the central and western regions is not significant. This is because the regional differences of China's export enterprises are very significant, and the eastern region is much more international and open than the central and western regions. Most of the export enterprises are located in the eastern region with strong openness, which has a higher international degree and is more vulnerable to the impact of exchange rate appreciation. However, the enterprises in the central and western regions are located in the interior and have a lower degree of internationalization, so they are not sensitive to the impact of exchange rate appreciation. Another reason is that almost $95 \%$ of China's export-oriented enterprises are concentrated in the developed eastern regions, as is the proportion of the sample selected in this paper. Therefore, enterprises in the central and western regions may have the problem of statistical insignificance due to less sample size.

\subsection{Regression Results of Heterogeneity of Enterprise Characteristics}

In the previous basic regression, this paper has analyzed the influence of enter- 
prise characteristic variables on the enterprises exiting or entering export markets. However, considering that enterprises are faced with exchange rate appreciation, what this paper is more interested in is the marginal impact of enterprise characteristics on the probability of enterprises exiting, will it increase or reduce the probability of enterprises to exiting from export markets? This will be the focus of this part of the study.

Table 5. Regression results of different enterprise ownership and enterprise in different regions.

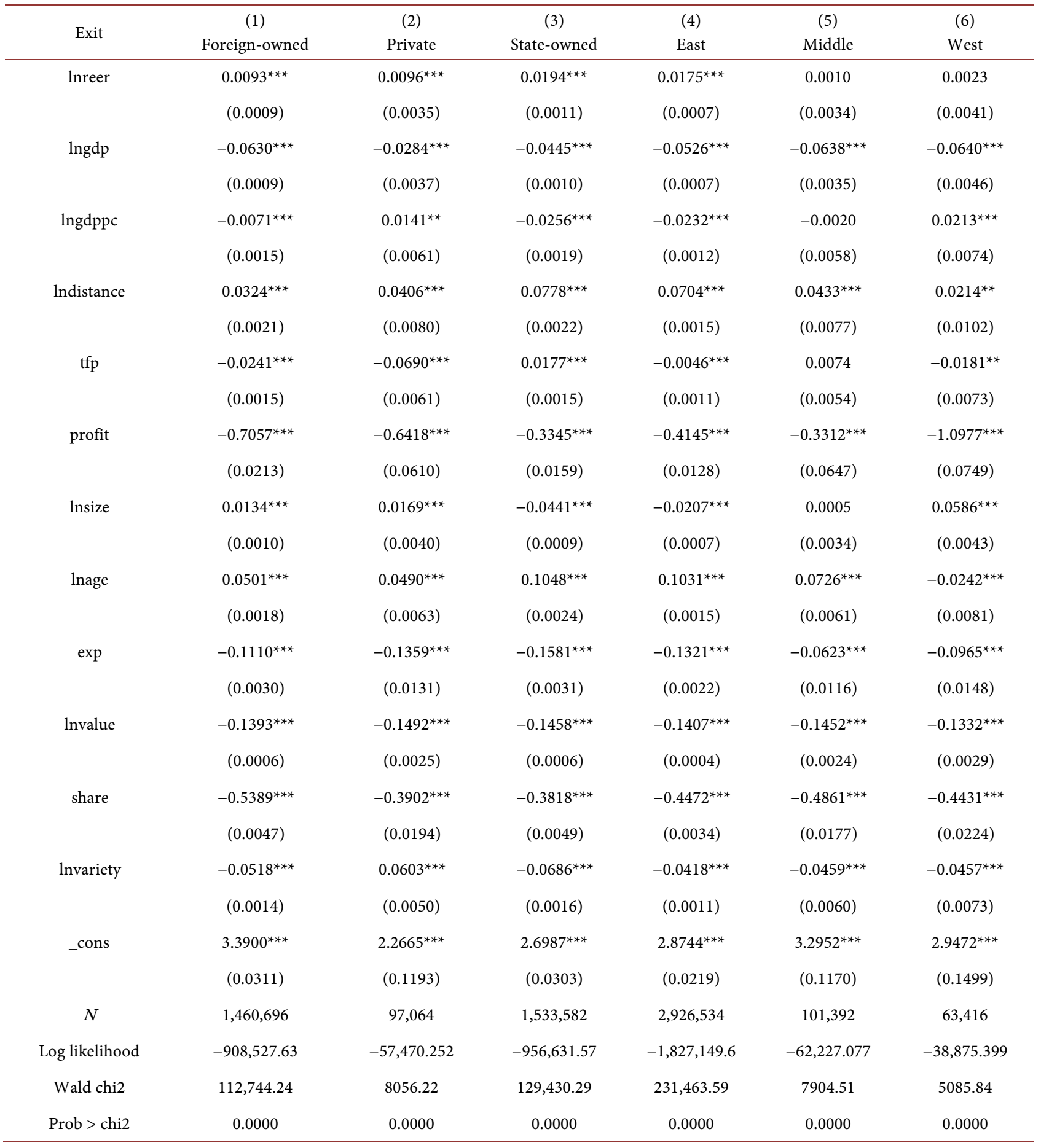


Firstly, the interaction term between the exchange rate and the enterprise characteristics is obtained by multiplying the enterprise characteristic variables with the real effective exchange rate of $\mathrm{RMB}$, and the interaction term is included in the regression model. We will investigate the influence of different enterprise characteristics on the enterprise exit probability when faced with the same exchange rate risk by examining the coefficient of the interaction term.

Table 6 shows the regression results of adding heterogeneity of enterprise characteristics. Columns (1) to (5) are the regression results of gradually adding the interaction terms. Among them, the coefficient of RMB real effective exchange rate is still significantly positive, while the regression coefficients of the interaction terms Inreer ${ }^{*} t f p$, Inreer ${ }^{*}$ profit, Inreer ${ }^{*}$ Insize, Inreer ${ }^{*}$ Inage and Inreer ${ }^{*} \exp$ are all significantly negative. That suggests the characteristic variables of enterprise productivity, profit margins, enterprise scale and enterprise export experience will reduce the positive impact of $\mathrm{RMB}$ real effective exchange rate on enterprises exiting from export markets. And the higher the enterprise profit margins and productivity is and the bigger enterprises size is and the more enterprises export experience has, the stronger the margin effect of inhibition will be. These characteristics reflect that the better operation status of enterprises is, the stronger the ability of enterprises to fight against exchange rate risk is, so as to effectively reduce the probability of enterprises exiting from export markets caused by exchange rate appreciation.

\section{Conclusion}

This paper focuses on the impact of exchange rate fluctuations on the dynamic change of enterprises entering and exiting export markets. In terms of the use of data, taking the "enterprise-product-destination" as the research object in this paper can avoid the aggregation bias of the summed exchange rate, and at the same time, it can also avoid the possible endogenous problem in the measurement process of the enterprise-level exchange rate index. The main conclusions are as follows: the appreciation of RMB exchange rate will significantly increase the probability of enterprises exiting from export markets and reduce the probability of enterprises entering export markets; considering the differences in enterprise ownership, it is found that when faced with the appreciation of RMB real effective exchange rate, foreign-owned enterprises are less likely to exit than private enterprises and state-owned enterprises, while state-owned enterprises have the highest exit probability. In addition, enterprises in the eastern region are vulnerable to the adverse impact of the appreciation of the real effective exchange rate of the RMB, while those in the central and western regions are not sensitive. Finally, the moderating effect with the incorporation of enterprise characteristic variables shows that such factors as enterprise productivity, enterprise profit margin, enterprise size and enterprise export experience will reduce the positive impact of RMB real effective exchange rate appreciation on enterprises exiting from export markets. 
Table 6. Regression results of heterogeneity of enterprise characteristics.

\begin{tabular}{|c|c|c|c|c|c|}
\hline & (1) & (2) & (3) & $(4)$ & (5) \\
\hline \multirow[t]{2}{*}{ lnreer } & $0.0375^{\star * *}$ & $0.0183^{\star * *}$ & $0.0387^{* * *}$ & $0.0270^{* * *}$ & $0.0209^{\star * *}$ \\
\hline & $(0.0033)$ & $(0.0007)$ & $(0.0031)$ & $(0.0016)$ & $(0.0009)$ \\
\hline \multirow[t]{2}{*}{$\operatorname{lngdp}$} & $-0.0532^{\star \star *}$ & $-0.0532^{\star * *}$ & $-0.0533^{\star * \star}$ & $-0.0532^{\star * \star}$ & $-0.0532^{\star * \star}$ \\
\hline & $(0.0007)$ & $(0.0007)$ & $(0.0007)$ & $(0.0007)$ & $(0.0007)$ \\
\hline \multirow[t]{2}{*}{ lngdppc } & $-0.0223^{* * *}$ & $-0.0223^{* * *}$ & $-0.0224^{* * *}$ & $-0.0224^{\star * *}$ & $-0.0223^{* * *}$ \\
\hline & $(0.0012)$ & $(0.0012)$ & $(0.0012)$ & $(0.0012)$ & $(0.0012)$ \\
\hline \multirow[t]{2}{*}{ Indistance } & $0.0684^{* * *}$ & $0.0682^{* * *}$ & $0.0689^{* * *}$ & $0.0686^{* * *}$ & $0.0686^{* * *}$ \\
\hline & $(0.0015)$ & $(0.0015)$ & $(0.0015)$ & $(0.0015)$ & $(0.0015)$ \\
\hline \multirow[t]{2}{*}{$\mathrm{tfp}$} & -0.0010 & $-0.0053^{\star * \star}$ & $-0.0052^{\star * \star}$ & $-0.0052^{* * *}$ & $-0.0052^{\star * *}$ \\
\hline & $(0.0012)$ & $(0.0010)$ & $(0.0010)$ & $(0.0010)$ & $(0.0010)$ \\
\hline \multirow[t]{2}{*}{ profit } & $-0.4365^{\star * *}$ & $-0.3560^{\star * *}$ & $-0.4382^{* * *}$ & $-0.4380^{* * *}$ & $-0.4375^{\star * *}$ \\
\hline & $(0.0124)$ & $(0.0154)$ & $(0.0124)$ & $(0.0124)$ & $(0.0124)$ \\
\hline \multirow[t]{2}{*}{ lnsize } & $-0.0166^{\star * *}$ & $-0.0167^{* * *}$ & $-0.0136^{\star * *}$ & $-0.0166^{\star * \star}$ & $-0.0166^{\star * *}$ \\
\hline & $(0.0006)$ & $(0.0006)$ & $(0.0008)$ & $(0.0006)$ & $(0.0006)$ \\
\hline \multirow[t]{2}{*}{ lnage } & $0.1017^{\star * *}$ & $0.1016^{* * *}$ & $0.1019^{* * *}$ & $0.1085^{\star * *}$ & $0.1016^{* * *}$ \\
\hline & $(0.0014)$ & $(0.0014)$ & $(0.0014)$ & $(0.0017)$ & $(0.0014)$ \\
\hline \multirow[t]{2}{*}{$\exp$} & $-0.1319^{\star * *}$ & $-0.1319^{* * *}$ & $-0.1319^{* * *}$ & $-0.1320^{\star * *}$ & $-0.1218^{\star * *}$ \\
\hline & $(0.0021)$ & $(0.0021)$ & $(0.0021)$ & $(0.0021)$ & $(0.0025)$ \\
\hline \multirow[t]{2}{*}{ lnvalue } & $-0.1403^{* * *}$ & $-0.1403^{* * \star}$ & $-0.1403^{* * *}$ & $-0.1403^{* * *}$ & $-0.1403^{* * *}$ \\
\hline & $(0.0004)$ & $(0.0004)$ & $(0.0004)$ & $(0.0004)$ & $(0.0004)$ \\
\hline \multirow[t]{2}{*}{ share } & $-0.4467^{\star \star *}$ & $-0.4468^{\star * *}$ & $-0.4469^{* * *}$ & $-0.4468^{\star * *}$ & $-0.4467^{\star * *}$ \\
\hline & $(0.0033)$ & $(0.0033)$ & $(0.0033)$ & $(0.0033)$ & $(0.0033)$ \\
\hline \multirow[t]{2}{*}{ lnvariety } & $-0.0451^{\star * *}$ & $-0.0452^{\star * *}$ & $-0.0452^{* * *}$ & $-0.0451^{\star * *}$ & $-0.0451^{\star * *}$ \\
\hline & $(0.0011)$ & $(0.0011)$ & $(0.0011)$ & $(0.0011)$ & $(0.0011)$ \\
\hline \multirow[t]{2}{*}{ lnreer*tfplp } & $-0.0033^{\star * \star}$ & & & & \\
\hline & $(0.0005)$ & & & & \\
\hline \multirow[t]{2}{*}{ lnreer ${ }^{\star}$ profit } & & $-0.0581^{* * \star}$ & & & \\
\hline & & $(0.0065)$ & & & \\
\hline \multirow[t]{2}{*}{ lnreerlnsize } & & & $-0.0024^{\star * \star}$ & & \\
\hline & & & $(0.0003)$ & & \\
\hline \multirow[t]{2}{*}{ lnreerlnage } & & & & $-0.0049^{* * *}$ & \\
\hline & & & & $(0.0007)$ & \\
\hline \multirow[t]{2}{*}{$\ln r e e{ }^{\star} \exp$} & & & & & $-0.0077^{\star * *}$ \\
\hline & & & & & $(0.0010)$ \\
\hline \multirow[t]{2}{*}{ _cons } & $2.8594^{* * *}$ & $2.8851^{* * *}$ & $2.8550^{* * *}$ & $2.8699 * * *$ & $2.8769^{* * *}$ \\
\hline & $(0.0218)$ & $(0.0213)$ & $(0.0218)$ & $(0.0215)$ & $(0.0214)$ \\
\hline$N$ & $3,091,342$ & $3,091,342$ & $3,091,342$ & $3,091,342$ & $3,091,342$ \\
\hline Log likelihood & $-19,29812.7$ & $-1,929,794.1$ & $-1,929,806$ & $-1,929,807.2$ & $-1,929,801.2$ \\
\hline Wald chi2 & $242,864.52$ & $242,889.53$ & $242,863.40$ & $242,855.66$ & $242,912.55$ \\
\hline Prob $>$ chi2 & 0.0000 & 0.0000 & 0.0000 & 0.0000 & 0.0000 \\
\hline
\end{tabular}


This paper studies the impact of exchange rate fluctuations on enterprises' export decisions, and has made some achievements in empirical research. However, due to the limited academic level of this paper, it has not done more in-depth exploration and research, so it still has some limitations and needs to be improved in the future work. First, the data samples selected in this paper are from 2000 to 2007, which still exists the problem of relatively old time span. At the same time, nearly $90 \%$ of the samples of the final retained enterprises after the merger are deleted, which also has a certain impact on the empirical results. Second, although the influence mechanism is analyzed in this paper, the mathematical model is not derived in detail in the theoretical research, which has some defects in the basic hypothesis. In view of this, longer time spans and more detailed mathematical model derivation will be further studied in the future work.

\section{Conflicts of Interest}

The author declares no conflicts of interest regarding the publication of this paper.

\section{References}

Baggs, J., Beaulieu, E., \& Fung, L. (2009). Firm Survival, Performance, and the Exchange Rate Shocks. Canadian Journal of Economics, 42, 393-421. https://doi.org/10.1111/j.1540-5982.2009.01513.x

Berman, N., Martin, P., \& Mayer, T. (2012). How Do Different Exporters React to Exchange Rate Fluctuation? Quarterly Journal of Economics, 127, 437-492. https://doi.org/10.1093/qje/qjr057

Berthou, A., \& Fontagné, L. (2013). How Do Multiproduct Exporters React to a Change in Trade Costs? Scandinavian Journal of Economics, 115, 326-353. https://doi.org/10.1111/sjoe.12006

Bini-Smaghi, L. (1991). Exchange Rate Variability and Trade: Why Is It So Difficult to Find Any Empirical Relationship? Applied Economics, 23, 927-935. https://doi.org/10.1080/00036849100000041

Bloom, N., Bond, S., \& Reenen, J. V. (2007). Uncertainty and the Dynamics of R\&D. American Economic Review, 97, 250-255. https://doi.org/10.1257/aer.97.2.250

Bonaime, A., Gulen, H., \& Ion, M. (2018). Does Policy Uncertainty Affect Mergers and Acquisitions? Journal of Financial Economics, 129, 531-558. https://doi.org/10.1016/j.jfineco.2018.05.007

Chattrejee, A., Dix-Carneiro, R., \& Vichyanond, J. (2013). Multi-Product Firms and Exchange Rate Fluctuations. American Economic Journal: Economic Policy, 5, 77-110. https://doi.org/10.1257/pol.5.2.77

Dixit, A. (1989). Hysteresis, Import Penetration, and Exchange Rate Pass-Through. Quarterly Journal of Economics, 104, 205-228. https://doi.org/10.2307/2937845

Dornbusch, R. (1987). Exchange Rates and Prices. American Economic Review, 77, 93-106.

Eckel, C., \& Neary, J. P. (2010). Multi-Product Firms and Flexible Manufacturing in the Global Economy. Review of Economic Studies, 77, 188-217. https://doi.org/10.1111/j.1467-937X.2009.00573.x

Esteve-perez, S., Requena-Silvente, F., \& Psllardo-lopez, V. J. (2013). The Duration of 
Firm-Destination Export Relationships: Evidence from Spain, 1997-2006. Economic Inquiry, 51, 159-180. https://doi.org/10.1111/j.1465-7295.2012.00460.x

Feenstra, R. C. (1989). Symmetric Pass-Through of Tariffs and Exchange Rates under Imperfect Competition: An Empirical Test. Journal of International Economics, 27, 25-45. https://doi.org/10.1016/0022-1996(89)90076-7

Foster, L., Haltiwanger, J. C., \& Krizan, C. J. (2001). Aggregate Productivity Growth: Lessons from Microeconomic Evidence. NBER Working Paper, No. 6803.

Frankle, J. A., \& Wei, S. J. (2007). Assessing China's Exchange Rate Regime. Economic Policy, 22, 575-627. https://doi.org/10.1111/j.1468-0327.2007.00185.x

Freund, C., Chang, H., \& Wei, S. J. (2011). China's Trade Response to Exchange Rate. In The 68th International Atlantic Economic Conference.

Fu, D., \& Wu, Y. (2014). Export Survival Pattern and Its Determinants: An Empirical Study of Chinese Manufacturing Firms. Asian-Pacific Economic Literature, 28, 161-177. https://doi.org/10.1111/apel.12050

Fung, L. (2008). Large Real Exchange Rate Movements, Firm Dynamics, and Productivity Growth. The Canadian Journal of Economics, 41, 391-424. https://doi.org/10.1111/j.1365-2966.2008.00468.x

Gorg, H., Kneller, R., \& Muraközy, B. (2012). What Makes a Successful Export? Evidence from Firm-Product-Level Data. Canadian Journal of Economics, 45, 1332-1368. https://doi.org/10.1111/j.1540-5982.2012.01734.x

Handley, K. (2014). Exporting under Trade Policy Uncertainty: Theory and Evidence. Journal of International Economics, 94, 50-66. https://doi.org/10.1016/j.jinteco.2014.05.005

Hess, W., \& Persson, M. (2011). Exploring the Duration of EU Imports. Review of World Economics, 147, 665-692. https://doi.org/10.1007/s10290-011-0106-x

Levinsohn, J., \& Petrin, A. (2003). Estimating Production Functions Using Inputs to Control for Unobservables. Review of Economic Studies, 70, 317-341. https://doi.org/10.1111/1467-937X.00246

Manova, K., \& Zhang, Z. W. (2012). Export Prices across Firms and Destinations. The Quarterly Journal of Economics, 127, 379-436.

Melitz, M. J. (2003). The Impact of Trade on Intra-Industry Reallocations and Aggregate Industry Productivity. Econometrica, 71, 1695-1725.

https://doi.org/10.1111/1468-0262.00467

Melitz, M. J., \& Ottaviano, G. I. P. (2008). Market Size, Trade, and Productivity. Review of Economic Studies, 75, 295-316. https://doi.org/10.1111/j.1467-937X.2007.00463.x

Obstfeld, M., \& Rogoff, K. (2000). The Six Major Puzzles in International Macroeconomics: Is There a Common Cause? NBER Macroeconomics Annual, 15, 339-390. https://doi.org/10.1086/654423

Osnago, A., Piermartini, R., \& Rocha, N. (2015). Trade Policy Uncertainty as Barrier to Trade. WTO Staff Working Paper.

Tang, H. W., \& Zhang, Y. F. (2012). Exchange Rates and the Margins of Trade: Evidence from Chinese Exporters. CESifo Economic Studies, 58, 671-702. https://doi.org/10.1093/cesifo/ifs006

Tomlin, B., \& Fung, L. (2010). The Effect of Exchange Rate Movements on Heterogeneous Plants: A Quantile Regression Analysis. Bank of Canada Working Paper, No. 25.

Upward, R., Wang, Z., \& Zheng, J. H. (2013). Weighing China's Export Basket: The Domestic Content and Technology Intensity of Chinese Exports. Journal of Comparative Economics, 41, 527-543. https://doi.org/10.1016/j.jce.2012.07.004 